\title{
Prospects for Geothermal Energy Conversion through a Hybrid Combined Cycle Power Plant
}

\section{Böszörményi, G. Böszörményi}

The demand for more intensive utilization of energy sources is getting more important with the forthcoming European Union membership of the Slovak Republic. Lack of resources and poor exploitaition of available resources can be a very difficult problem for energy policy. It is important to use technical solutions to minimize or eliminate this problem. The most beneficial progress could be achieved in the Košice basin where geothermal energy could have effective and multi-purpose use.

Keywords: combined cycle, geothermal energy, heat pump, biomass.

\section{Introduction}

Slovakia is extremely poor in fossil fuels and is consequently $90 \%$ dependent on imported energy sources. This is all the more significant because the national economy has been assessed to be three times more dependent on energy than the average of the EU economies. Intensified use of local renewable sources and raising efficiency should therefore be major priorities of the energy and environmental policy.

Since there are good conditions for conversion of biomass to energy, its utilization should be as usual as that of hydro energy. It is necessary to focus on usage of solar and geothermal energy since they are currently the least utilized energy sources (6\% and $2 \%$ ), if we do not take into account the almost negligible use of wind energy. While solar energy is suitable for use in projects in the range of some $\mathrm{kW}$, due to its low concentration, the power output from geothermal projects is significantly higher, and can be used for major projects. The idea of a geothermal project in Košice to utilize about $100 \mathrm{MW}$ of geothermal output and to provide the city with $2500 \mathrm{TJ} /$ year from 8 geothermal doublets is undoubtedly one of the boldest initiatives of its type in the world today. It could change the energy balance of the country in a relatively short period of time. As presented in [3] and [6], it seems that the company GEOTERM is prepared to solve the problems connected with exploitation and transportation of geothermal water into the area of TEKO (the company that owns the heating plant in Košice). Now it is the turn of this company to find a proper design to utilize this source that would improve its efficiency in comparison with the simple utilization of fossil fuel. The results of the study [4] show that this seems to be unreal in the case of direct use of geothermal heat in the District Heating Network (DHN). It is possible to increase the competitiveness of direct use through a heat pump that would intensify the utilization of the disposable enthalpy potential. The way to improve the efficiency of the geothermal project in Košice is by changing the basic philosophy. All the possible proposals should be technically and economically analyzed and compared in a feasibility study.

The aim to replace a part of TEKO that is reaching the end of its working life with a combined cycle CHP plant leads us to think of a non-traditional use of geothermal resources to support combined heat and power production. This could lead to an increase in power output for constant fossil fuel consumption or a decrease in fossil fuel consumption for constant power output. This concept requires the construction of a combined cycle power plant of a new generation - a combined cycle power plant with integrated geothermal support or a hybrid combined cycle power plant for heat and power production.

The principle of a hybrid geothermal power plant is already known. There is only one operating plant of this type. It is located in Honey Lake, California and has a power output of $35 \mathrm{MW}$. It is a steam cycle power plant that differs from the standard design by its source of energy, which is wood waste (biomass). For heating the feed water $22 \mathrm{~kg} / \mathrm{s}$ of geothermal water of $118^{\circ} \mathrm{C}$ are used. Using these parameters the maximum geothermal output can be $8 \mathrm{MW}$.

\section{The idea of a hybrid combined cycle power plant with heat and power production and integrated geothermal support}

The design of a combined cycle power plant with integrated geothermal support may have many variants. The main idea of this hybrid concept is to use geothermal energy to heat the feed water in the steam cycle, which is more advantageous than mere direct use in the DHN for the following reasons:

- The temperature of the condensate in the steam cycle is $30 \mathrm{~K}$ lower than the temperature of the returning primary water in the DHN, which allows significantly better use of the enthalpy of secondary geothermal water, in our case by $50 \%$. This means that the same geothermal output can be obtained from half of the geothermal doublets. This leads to a saving of $50 \%$.

- The use of this output is much higher because power production is provided throughout the year, while heating has a seasonal character.

Such integration of a geothermal source into a combined cycle power plant can be combined with direct supply of the 


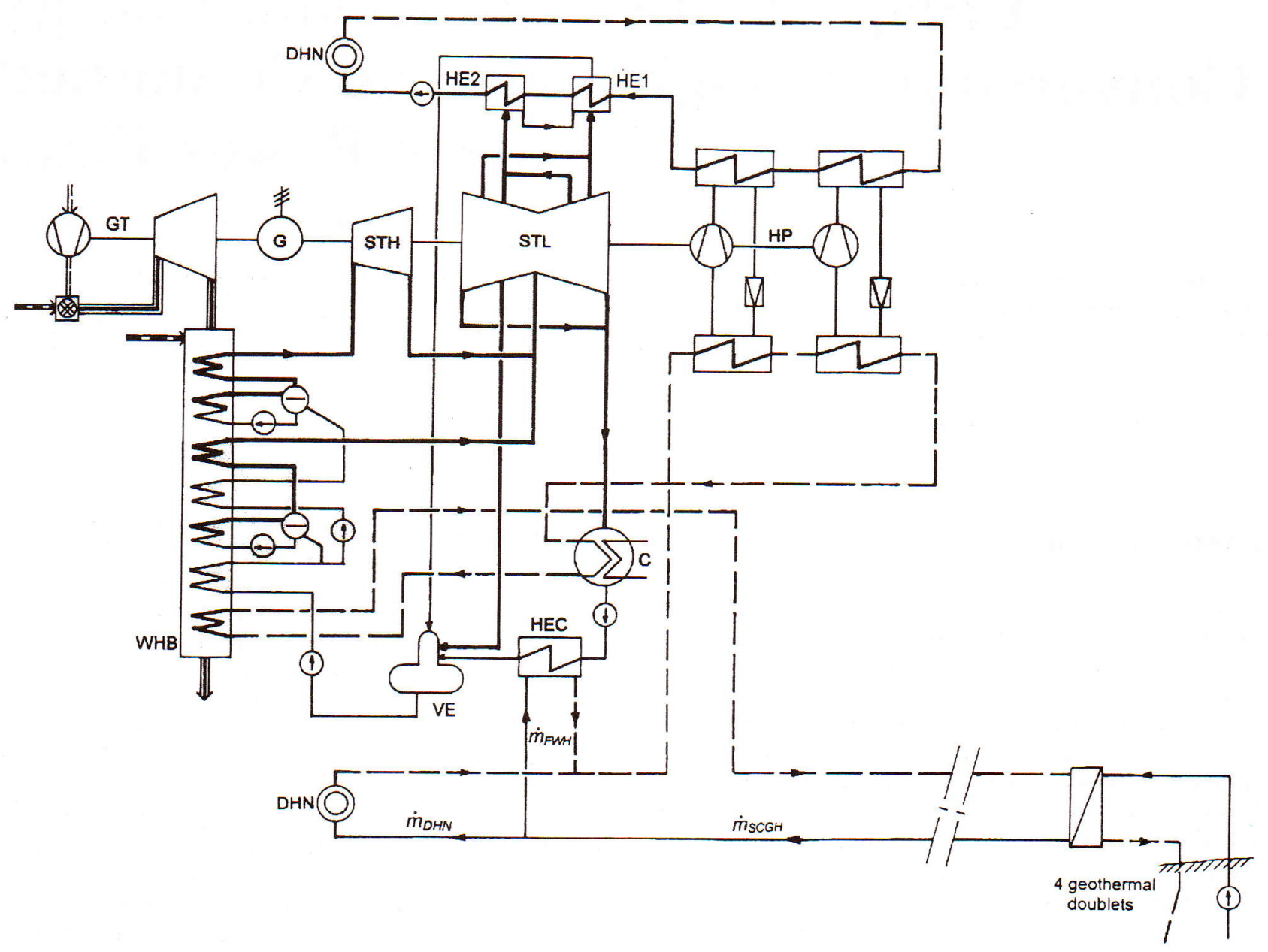

Fig. 1: Principal scheme of a combined cycle power plant with heat extraction including integrated geothermal support - winter period

DHN. This seems to be advantageous also in the case of the geothermal project in Košice. The idea of a hybrid combined cycle power plant for heat and power production could be based on the same particular processes for each variant. The principle of these processes is shown in Fig. 1.

The stream of the secondary geothermal water $\dot{m}_{S C G H}$ would be divided into two parts. One of them $\dot{m}_{F W H}$ would be used for heating the feed water (condensate) in the heat exchanger HEC between the condenser $\mathrm{C}$ of the steam turbine and vapor extractor VE. The second part $\dot{m}_{D H N}$ would be used directly in the DHN. After mixing the returning flows that were cooled down to different degrees, the heat will be pumped from the resulting flow, using the heat pump HP for indirect utilization in the DHN. The heating water in the condenser of the heat pump can be overheated as required in the waste heat boiler WHB, as assumed in [1]. It seems to be more reasonable to use the extracted steam from the low-pressure stage of steam turbine STL for heating in the heat exchangers HE1 and HE2 in spite of the decrease in geothermal output that can be used for heating the feed water in the winter period. In the evaporator of the heat pump the secondary geothermal water can be cooled to such an extent that it can be used for cooling the condenser $\mathrm{C}$ of the steam turbine. Part of the heat losses can branch away from condenser $\mathrm{C}$. The implementation of this arrangement would be justified especially in the summer period. Finally, in the waste heat boiler WHB the secondary geothermal water can be heated by the heat losses from the outgoing flue gases at the same temperature as is assumed in the case of only direct utilization in the DHN. The flue gases can be cooled down in this way below the dew point and in addition to the sensible heat also the latent heat of the flue gases can branch away. This is conditional on solving many technical problems that can increase the costs. The heat losses of the waste heat boiler and condenser, which constitute a substantial part of the heat losses for standard design of the combined cycle, will be accumulated through the geothermal water being re-injected into the earth's crust. It would be better to use this water in recreational facilities or in agriculture (this was not assumed in Fig. 1). The temperature of the returning secondary water must correspond to the demand for optimal re-injection of primary water.

The parameters of the steam cycle should be adjusted to the described processes. The power output of the steam cycle would be determined by the amount of condensate and indirectly by the flow of secondary geothermal water used for heating the feed water. Considering the high demands for the effectiveness of conversion of natural gas to power, when the 
maximum geothermal heat would be used, such a stream is expected when there are at least two pressure levels of superheated steam.

The heat pump being integrated into the combined heat and power production system plays a key role in its effective function with the geothermal source. Therefore its design must be adjusted to this requirement. The first results show that the heat pump should be designed at least in two stages, but it is necessary to analyze whether the economic contribution of a more effective three-stage design would not justify the higher costs. If the machinery of the combined cycle power plant were on a single shaft with the machinery of the heat pump, the costs would be reduced. In the case of the concept described here, progressive energy technologies enable very effective use of geothermal heat in comparison with only direct use in the DHN, especially in the summer period (see in Fig. 2).

The operation of direct use in the DHN and of steam extraction can be stopped during summer, when there is lower demand for temperature and lower heat consumption is needed for heating the feed water. This would bring an increase in the power output of the steam turbine and would free a significant geothermal source of high temperature that could be used for absorption cooling in absorption chiller $A C$ and then for warming up the heating water in heat exchanger HE3. The necessary thermal output in the DHN can be obtained from the geothermal source using heat pump HP and heat exchanger HE3 operating together. In the condenser of the heat pump the heating water would be warmed to $60{ }^{\circ} \mathrm{C}$ by the heat pumped from the secondary geothermal water that would be cooled in the heat exchangers HEC and HE3. This water would then be overheated to the desired temperature in the heat exchanger by the secondary geothermal water previously used for absorption cooling.

Absorption chillers are commonly used for air conditioning, which is justified only for higher ambient temperatures of relatively short duration. In this case, it would be more rational to use this cooling capacity for cooling the air entering the compressor in the heat exchanger HEA, since this would even operate for an ambient temperature of $15{ }^{\circ} \mathrm{C}$. A decrease in air temperature by $10 \mathrm{~K}$ results in an increase in power output of the gas turbine GT by $6 \%$. This absorption chiller can be effectively used as power source for consumption peaks, since the ambient temperature is higher for load peaks. Such un-traditional conversion of geothermal heat to power would be achieved, when heat losses from absorption cooling could be accumulated through the secondary geothermal water. The heat losses of absorption refrigerating systems constitute approximately $170 \%$ of the thermal input used for the operation of the system, and branching them away is expensive.

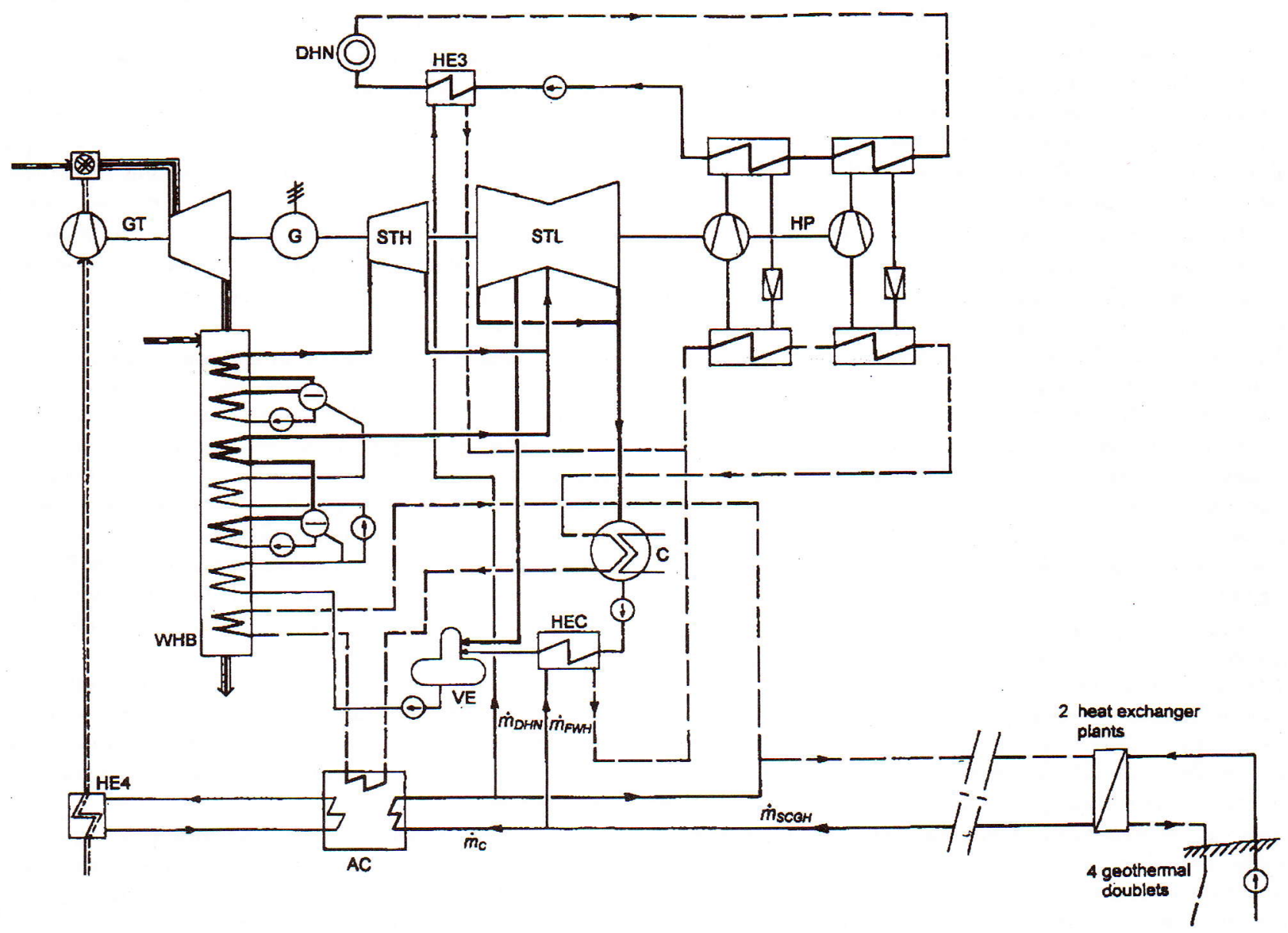

Fig. 2: Principal scheme of a combined cycle power plant with heat extraction including integrated geothermal support - summer period 


\section{Prospects for integrating the geothermal source of the Košice basin into the structure of a hybrid combined cycle power plant}

The results of the analysis show that a geothermal source could be used in a hybrid combined cycle power plant based on a gas turbine with 260 MW power output (ISO requirement) without overheating. If the capacity of 4 geothermal doublets instead of the planned 8 doublets were to be utilized and the stream of secondary geothermal water $\dot{m}_{S C G H}=240 \mathrm{~kg} / \mathrm{s}$ were to be divided in the ratio $\dot{m}_{D H N}: \dot{m}_{F W H}=5: 3$, the power output of the steam turbine in the winter period would be approximately $120 \mathrm{MW}$ and in the summer period for $15{ }^{\circ} \mathrm{C}$ ambient temperature approx. 135 MW. The total thermal output would be $150 \mathrm{MW}$ in the winter period and $45 \mathrm{MW}$ in the summer period.

In the summer period the heat from fossil fuel (natural gas) would be used only for power production. The power required for compression in the heat pump is about $7 \mathrm{MW}$. If the total unused capacity of the geothermal source (about $12 \mathrm{MW}$ ) were to be used for absorption cold production, the air at the inlet of the compressor would be cooled by $12 \mathrm{~K}$. For an ambient temperature of $20^{\circ} \mathrm{C}$ this would result in an increase in power output by $19 \mathrm{MW}$. This indirect conversion of geothermal heat is much more efficient than technologies for direct conversion (for example the Organic Rankine Cycle or Kalina cycle), which operate with $10 \%$ efficiency.

The described concept would enable the use of about $90 \mathrm{MW}$ of geothermal output in the summer period for heating the feed water, for warming up the heating water and for absorption cooling. The required thermal output of the city for domestic warm water is about $45 \mathrm{MW}$.

The main contribution of the operation of a hybrid combined cycle power plant with heat extraction that would replace the TEKO block that is reaching the end of its working life, would be that more than $2500 \mathrm{TJ} / \mathrm{year}$ from 4 doublets in the DHN only during the processes of heating would be utilized, as against using less thermal energy from 8 geothermal doublets in the case of only direct use.

In comparison with the aim described in [3] this involves a saving on investment costs of about 25 mil. USD, and operating costs could be reduced by $50 \%$. The selling price of geothermal heat could be significantly lower, and money would become available for investing in the rebuilding of TEKO.

Apart from its use in heating processes, the secondary geothermal water would also be used in cooling processes. The useful cooling effect in the condenser of the steam turbine and in the absorption refrigerating system would have positive effect on the economic efficiency of the operation of the plant. If the heat losses were used and/or the amount of consumed geothermal heat were measured at the input of the source, the economic efficiency could be even higher. At all events, the thermal load of the environment would be lower and through the accumulation of heat losses the operating life of the mains would be longer.

Finally, a hybrid combined cycle power plant with the described structure would be environmentally much cleaner than any source based on fossil fuel. Therefore this plant could have strong position on a liberal energy market.

\section{The idea of a hybrid combined cycle power plant based on a combination of natural gas, biomass and geothermal heat}

In consequence of intensive multi-purpose utilization of geothermal heat in the Košice basin, four of the eight geothermal doublets would be freed according to the described concept. The need for a more significant proportion of renewable sources in the energy balance of Slovakia motivates a search for a reasonable use of this capacity, if possible close to the geothermal mains. Since there is no demand for more thermal energy from households in this location, we have to consider

- conversion of geothermal heat into power,

- utilization of geothermal heat in technology processes.

The second alternative raises some important issues. There is a requirement to reduce emissions from power production. Direct conversion of geothermal heat to power is attractive from this point of view.

The anticipated temperature level of the geothermal heat (about $125^{\circ} \mathrm{C}$ ) is too low to consider direct conversion to power. Indirect conversion through ORC technology or a Kalina cycle could be implemented with low efficiency and high costs. Moreover, large amounts of the special medium used in these technologies would be a potential treat to the environment. For this reason, conversion of geothermal heat is recommended in a hybrid combined cycle power plant designed, as described above. In this case only power would be produced and therefore integration of the heat pump is not justified. Due to the high demand for natural energy it would be suitable to extend the principle of hybrid power plants to another renewable source. First of all we have to consider biomass.

The principal scheme for an alternative design for a hybrid combined cycle power plant based on a combination of natural gas, biomass and geothermal heat is shown in Fig. 3. Its structure is designed to make the conversion of natural gas as efficient as possible. For these reasons, processes of low pressure and high pressure evaporation that cause most singificant losses due to irreversibilities are moved from the waste heat boiler WHB to an independent boiler BB where biomass will be burned. Consequently, the partial efficiency of conversion of natural gas to power could reach a value higher than $60 \%$.

Use of geothermal heat for heating the feed water in the heat exchanger HEC and for absorption cooling in absorption chillers $\mathrm{AC}$ would have equal importance. In our case it could also be used for drying the biomass before burning in the drier $\mathrm{BD}$.

In the energy balance of such a hybrid power plant, biomass would be dominant. The power output of the gas turbine should be lower and that of the steam turbine should be higher, as described above. Another alternative would be advantageous when the steam cycle operates in the basic load and a gas turbine operates in the half-peak load. 


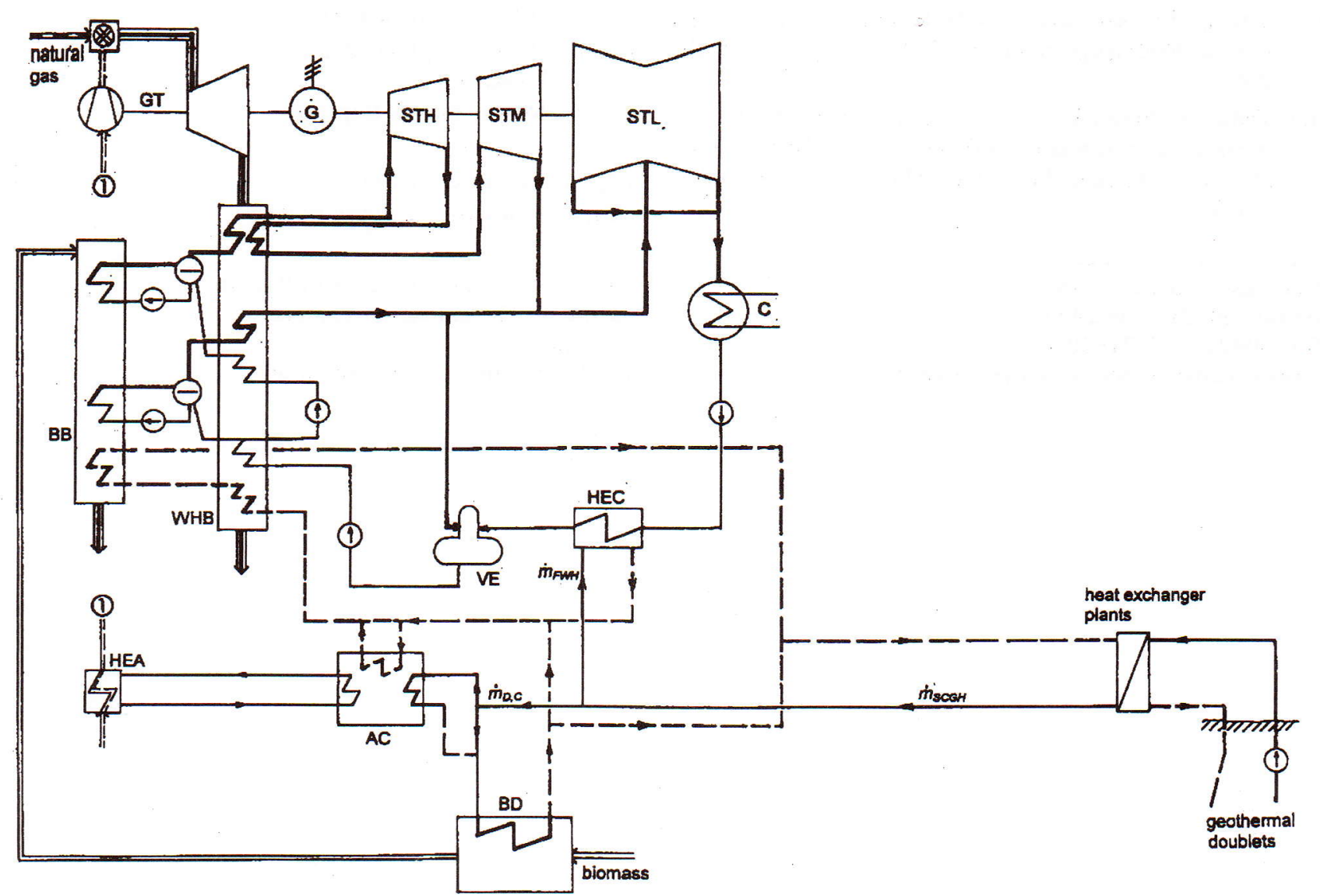

Fig. 3: Principal scheme of a hybrid combined cycle power plant based on a combination natural gas, biomass and geothermal heat

\section{Conclusions}

The hybrid combined cycle power plant based on the described concept would be the largest plant of this type. About 90 mil. $\mathrm{m}^{3}$ of natural gas could be saved, which would lead to a reduction of $\mathrm{CO}_{2}$ by $220000 \mathrm{t} /$ year. The real savings would be higher when taking into account the emissions produced by the plant being replaced. The construction of such a unique plant would contribute to effective conversion of fossil fuel energy to useful energy forms using geothermal energy. This would be a chance to improve the credibility of Slovak energy policy, since progress in cogeneration systems and more intensive use of renewable sources are priorities.

The specification of the optimal variant of this concept and also the overall evaluation of its power supply, economic and environmental potential should form the subject of a very serious feasibility study. The results could positively affect the possible privatization of TEKO.

In spite of the possible contribution of the described concept to environmental policy, Slovak engineers have shown surprisingly little interest, less than that shown by engineers in foreign countries. The concept was presented at the seventh World Renewable Energy Congress in July 2002 in Köln, Germany and at the World Sustainable Energy Day in March 2002 in Wels, Austria.

Hybrid combined cycle power plants are a new generation of combined cycle power plants. They allow effective use of fossil and renewable sources. Consequently they allow power production with fewer environmental impacts than any standard plant. It is therefore desirable to move toward implementing concepts that have until now only been discussed. Košice basin has advantageous natural conditions to implement such a concept. While closure of the nuclear power plant at Jaslovské Bohunice and of all the brown coal-based power plants in Hungary is being planned, this opportunity should not be ignored. More intensive utilization of local renewable sources would then become a reality. Moreover, the chance to fulfill the strategic aims of the EU in the field of energy and environmental protection and to apply for financial support would not be wasted.

\section{References}

[1] Böszörményi, L., Böszörményi, G.: Zásobovanie Košíc geotermálnou energiou. Magazín Energia, Vol. 3., 2001, No. 3.

[2] Böszörményi, L., Böszörményi, G.: The Perspectives of Geothermal Energy Utilization in District Heating System of Košice City. World Renewable Energy Congress VII, PERGAMON, 2002.

[3] Geotermálna energia pre centrálne zásobovanie teplom v meste Košice. GEOTERM Košice, Košice 1999.

[4] Riešenie náhrady zastaralých zdrojou tepla v TEKO Košice. Výskumný ústav energetický EGÚ Bratislava, Bratislava, 1996. 
[5] Tuschy, I.: Thermische Hybridkraftwerke zur Krafterzeugung aus Niedertemperaturwärme. VDI-Verlag, Düsseldorf, 2001.

[6] Váňa, O., Beňovský, V., Schustr, P., Pavlas, P.: Využití geotermálních zdrojů pro zásobováni teplem a elektrickou energii v Košicích. Acta Mechanica Slovaca, Košice, 2000, No. 3.

Doc. Ing. Ladislav Böszörményi, CSc. phone: 00421556024241

fax: 00421556321558

e-mail: Ladislav.Boszormenyi@tuke.sk
Technical University of Košice Faculty of Civil Engineering Vysokoškolská 4

04201 Košice, Slovak Republic

Ing. Gabriel Böszörményi

e-mail: G.Boszormenyi@sh.cvut.cz

Czech Technical University in Prague

Faculty of Mechanical Engineering

Technická 4

16607 Prague 6, Czech Republic 